\title{
Experimental Researchon Flow and Strength Properties of Blended Fibre Reinforced Self Compacting Concrete
}

\author{
Sk.Noor Ibrahim, S.V.Sathya Narayana, M.L.N Krishna Sai
}

\begin{abstract}
Self compacting concrete achieves compaction by itself without using mechanical vibration techniques. Addition of fibers to SCC results in increased performance mainly in flexure, and also in compressive strength. In this study both the flow and strength properties of single Fiber and blended fiber reinforced self compacting concrete are examined in comparison with control self compacting concrete. crimpled steel fibers having size of $0.45 \mathrm{~mm}$ diameter $x 12.5 \mathrm{~mm}$ length (aspect ratio 27.7) and $0.45 \mathrm{~mm}$ diameter $\times 20 \mathrm{~mm}$ length (aspect ratio 44.44) are used in the SCC mix at various percentages by weight of cement i.e. $0 \%$, $2 \%$, 4\% and $6 \%$. From the obtained results it can be seen that there is aadverse affect on flow properties. There is a moderate increase in the compressive strength, split tensile strength and considerable increase in the flexural strength of the self compacting concrete using the blended fibers at different percentages i.e. at $2 \%$ and $4 \%$, when compared to the single fiber reinforced self compacting concrete.

Index Terms-Self Compacting Concrete (SCC), Single Fiber Reinforced Self Compacting Concrete (SFRSCC), Blended Fiber Reinforced Self Compacting Concrete (BFRSCC), Super Plasticizer (SP)
\end{abstract}

\section{INTRODUCTION}

Self-compacting concrete is a variety of concrete which flows under it'sself weight and does not require any sort of vibration either manual or mechanical and has become a revolution in workable concrete placement. It will gives good finishing to the hardened surfaces. SCC best suits for placing concrete in form works with heavy reinforcement without the aid of any sort of vibration. SCC should ensure good balance between stability and deformability. SCC was first invented in 1980's by Japanese researches and is highly workable concrete and durable too. SCC production is more dependent on the mixing time, better mixing and needs more experience than the control concrete mix. And there is a need of skilled labour in producing good quality selfcompacting concrete. If a concrete is said to be a selfcompacting concrete it should fulfill the requirements of passing ability (through the narrow cross-sections), filling ability (through dense reinforcement) and resistance to segregation. Though, mix design is an adhoc procedure for self - compacting concrete, number of experimental investigations are carried out to find the suitable mix design and to find testing techniques of the same. The constituents of self - compacting concrete are same as ordinary concrete, containing, cement, fine aggregate (FA), coarse aggregate (CA), water and admixtures. To maintain the flow properties of self - compacting concrete which is a humungous

Revised Manuscript Received on April 12, 2019.

Sk.Noor Ibrahim

S.V.SathyaNarayana

M.L.N Krishna Sai difference, SCC must contain more fines content, super plasticizer along with viscosity modifying agents to some extent.

In simulation with control concrete, SCC possesses better strength because of good quality compaction, a slight increase in the tensile strength and better qualities in terms of bond strength and a similar fire resistance property.

\section{OBJECTIVE AND METHODOLOGY}

\section{A. Objective}

The objective of this project is to study the properties of blended fiber reinforced self compacting concrete .These properties includes flow and strength properties of blended fiber reinforced self compacting concrete.

The flow properties include:

(i)Filling Ability

(ii)Passing Ability

(iii)Resistance to Segregation

The strength properties include:

(i)Compressive Strength

(ii)Split Tensile Strength

(iii)Flexural Strength

\section{B. Methodology}

Self compacting concrete mix of M30 grade is adopted for the present study. The fiber reinforced self compacting concrete and blended fiber reinforced self compacting concrete mixes are obtained by adding fibers to SCC mix. Flow properties are examined using the following tests:

(i)Flow Table Test

(ii)V-Funnel Test

(iii)L-Box Test

Strength properties are examined using the following tests:

(i) Compressive strength on specimens of size $15 \mathrm{~cm} \times 15$ $\mathrm{cm} \times 15 \mathrm{~cm}$.

(ii) Split tensile strength on specimens of size $15 \mathrm{~cm}$ dia. $\mathrm{x}$ 30 cmheight.

(iii) Flexural strength on specimens of size $15 \mathrm{~cm}$ x 15 $\mathrm{cmx} 70 \mathrm{~cm}$.

\section{MATERIALS}

In this study materials like cement, fly ash, sand, coarse aggregate (CA), SP and water steel fibers are used. The properties of ingredients used in the mix are given in the

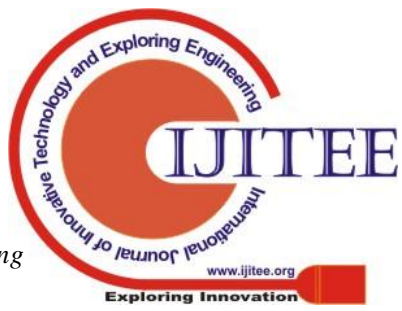


following sections. It is proposed toexamine the effect of steel fibers and on the strength and durability of SCC. The ingredients used in the mix are tested to obtain their properties as per the relevant IS codes.

\section{Cement}

Cement used for this study is Ordinary Portland Cement (OPC) of 53 grade.

\section{Fly ash}

Fly ash used for this study is obtained from Vijayawada thermal power plant, Vijayawada, AP.

Fine aggregate

Natural river sand grading zone-III is used as fine aggregate.

\section{Coarse aggregate}

Coarse aggregate of size confining to $10-12 \mathrm{~mm}$ is used in this study.

\section{Steel fibers}

Crimped steel fibers of size $0.45 \mathrm{~mm}$ diameter $\mathrm{x} 12.5 \mathrm{~mm}$ length (aspect ratio 27.78), $0.45 \mathrm{~mm}$ diameter $x 20 \mathrm{~mm}$ length (aspect ratio 44.44) are used.

\section{Super plasticizer}

Poly-carboxylic ether (MKY SP 200) type super plasticizer is used in mixes.

Water

\section{TEST PROCEDURE}

A suitable mix proportion is adopted for the study. Crimped fibers are added in different percentages. The following tests are carried out to study the flow properties and strength properties of the different SCC mixes.

\section{Slump flow test:}

Slump flow test is conducted to observe the segregation resistance of the concrete in absence of obstruction. The average diameter of the spread concrete is noted.
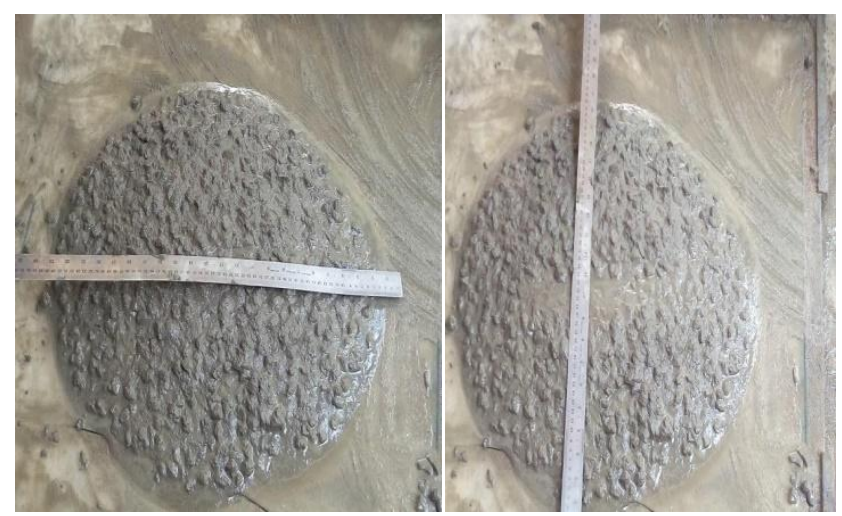

Fig. 1. Flow table with slump diameters D1 \& D2

\section{$V$ - Funnel test:}

This test assesses the filling capacity (flow ability) of SCC with 10-12 mm size aggregate being maximum. Around 12 liters of concrete is required to perform this test.

\section{L-Box test:}

This test is used to study the flow ability of SCC through narrow openings inclusive of spacing between reinforcing bars and other obstacles without segregation (or) blocking.

\begin{tabular}{|c|l|c|c|c|}
\hline \multirow{2}{*}{ S.No } & \multirow{2}{*}{ Method } & \multirow{2}{*}{ Units } & \multicolumn{2}{|c|}{$\begin{array}{c}\text { Typical range of } \\
\text { values }\end{array}$} \\
\cline { 4 - 5 } & & & Min. & Max. \\
\hline 1. & Slump flow test & $\mathrm{mm}$ & 650 & 800 \\
\hline 2. & T50 slump flow & $\mathrm{sec}$ & 2 & 5 \\
\hline 3. & V-Funnel test & $\mathrm{sec}$ & 6 & 12 \\
\hline 4. & L-Box test ( H2/H1) & & 0.8 & 1.0 \\
\hline
\end{tabular}

TABLE 1: Acceptance criteria forSCC

\section{Compression test:}

Concrete cubes with different SCC mix are prepared cured in standard procedure and tested at 28 days. Concrete cubes are tested for compressive strength in compression testing machine.

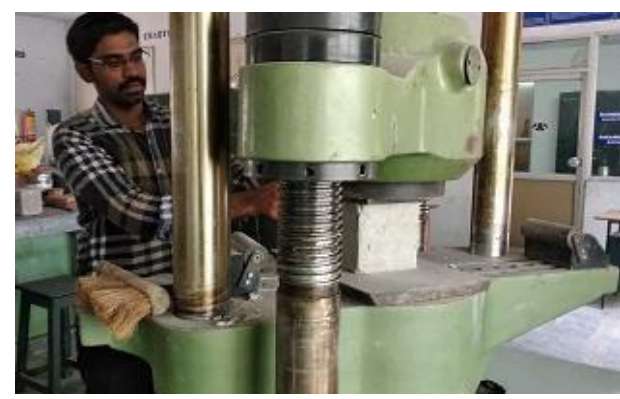

Fig.2.Compression test on cubes

Split tensile test:

Concrete cylinders are tested for split tensile strength in universal testing machine.

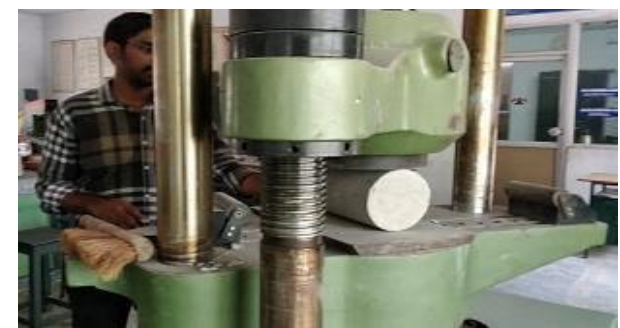

Fig.3.Split tensile test on cylinder

\section{Flexural test:}

Concrete beams are prepared in standard procedure and cured for 28 days. Beams are tested in universal testing machine under two point loading.

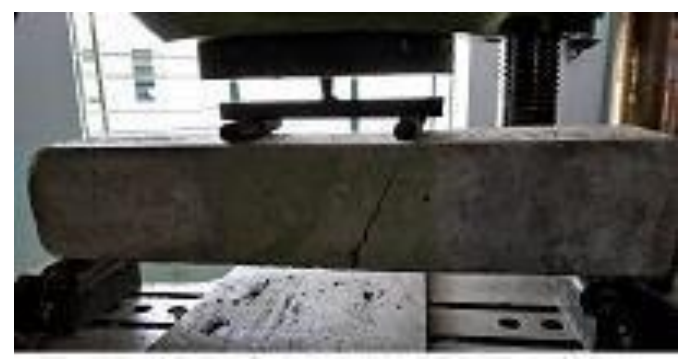

Fig.4.Flexural test on beam

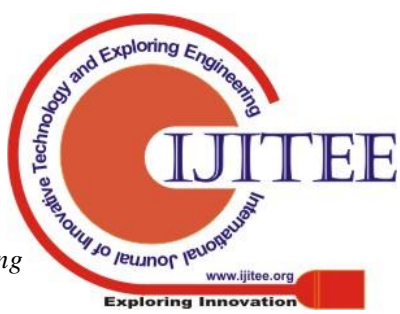




\section{TEST RESULTS}

TABLE 2: FLOW PROPERTIES

\begin{tabular}{|c|c|c|c|c|c|}
\hline \multirow{2}{*}{$\begin{array}{c}\text { Mix } \\
\text { Designation }\end{array}$} & \multicolumn{5}{|c|}{ Name of the experiment } \\
\cline { 2 - 6 } & \multicolumn{2}{|c|}{ Flow table } & V-funnel & \multicolumn{2}{c|}{ L-box } \\
\cline { 2 - 6 } & Time(sec) & $\begin{array}{c}\text { D avg. } \\
(\mathrm{mm})\end{array}$ & $\begin{array}{c}\text { Time } \\
(\mathrm{sec})\end{array}$ & Time(sec) & h2/h1 \\
\hline SCC0 & 2.83 & 700 & 6.82 & 6.09 & 0.85 \\
\hline SCC2SI & 2.86 & 675 & 6.9 & 6.53 & 0.81 \\
\hline SCC4SI & 3.6 & 673 & 7 & 6.63 & 0.79 \\
\hline SCC6SI & 3.93 & 635 & 7.2 & 6.85 & 0.61 \\
\hline SCC1SI+1SII & 2.49 & 665 & 7.45 & 7.23 & 0.8 \\
\hline SCC2SI+2SII & 3.11 & 665 & 7.48 & 7.36 & 0.79 \\
\hline
\end{tabular}

TABLE 3: STRENGTH PROPERTIES

\begin{tabular}{|c|c|c|c|}
\hline $\begin{array}{l}\text { Mix } \\
\text { Designation }\end{array}$ & $\begin{array}{l}\text { Compressive } \\
\text { strength } \\
\left(\mathrm{N} / \mathrm{mm}^{2}\right)\end{array}$ & $\begin{array}{l}\text { Split tensile } \\
\text { strength } \\
\left(\mathrm{N} / \mathrm{mm}^{2}\right)\end{array}$ & $\begin{array}{l}\text { Flexural } \\
\text { strength } \\
\left(\mathrm{N} / \mathrm{mm}^{2}\right)\end{array}$ \\
\hline SCC0 & 32.63 & 2.045 & 4.84 \\
\hline SCC2SI & 34.66 & 2.125 & 5.26 \\
\hline SCC4SI & 37.69 & 2.543 & 5.89 \\
\hline SCC6SI & 41.73 & 2.954 & 7.79 \\
\hline SCC1SI+1SII & 37.04 & 2.355 & 5.85 \\
\hline SCC2SI+2SII & 39.62 & 2.725 & 6.52 \\
\hline
\end{tabular}

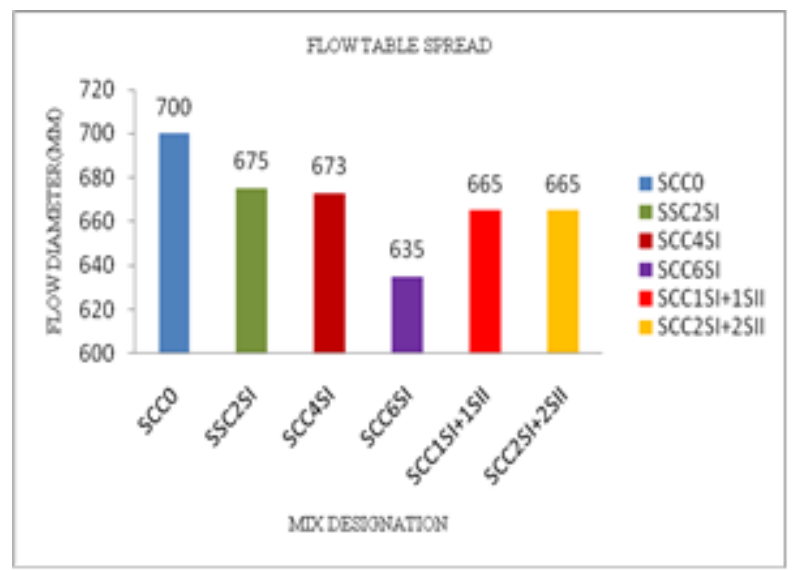

Fig.5.Variation of flow diameter for different mixes

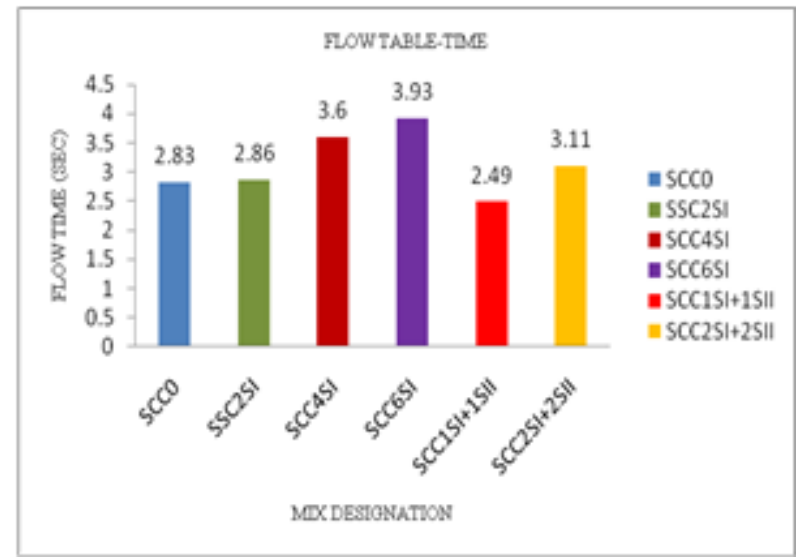

Fig.6.Variation of flow time for different mixes

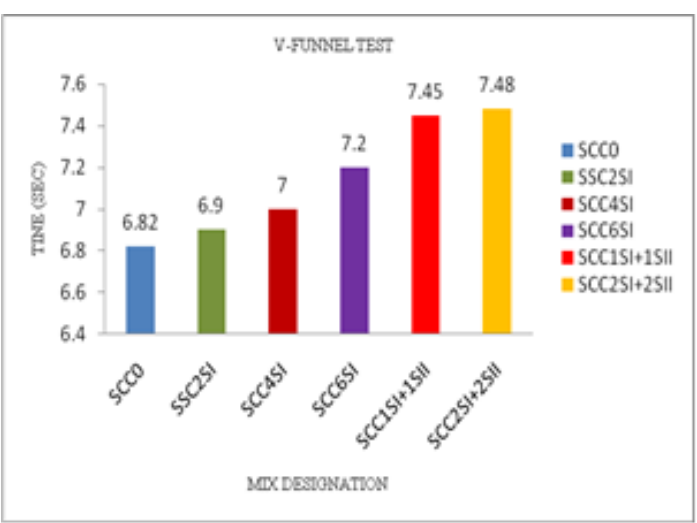

Fig.7.variation of V-funnel time for different mixes

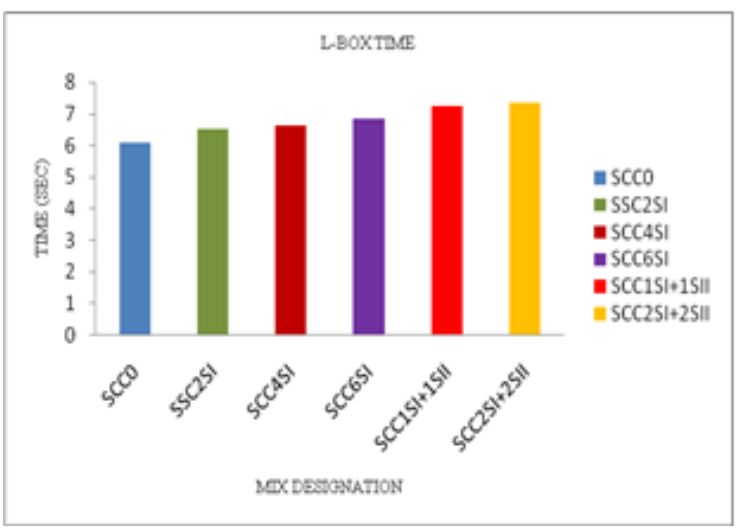

Fig.8.Variation of L-box time for different mixes

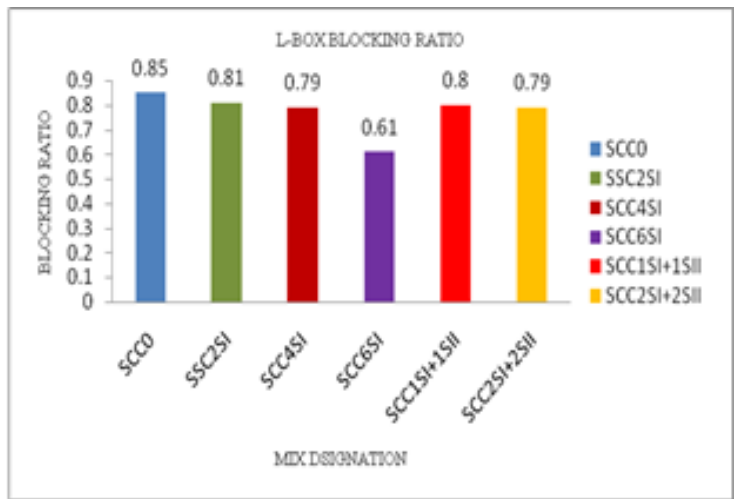

Fig.9.Variatin of blocking ratio for different mixes

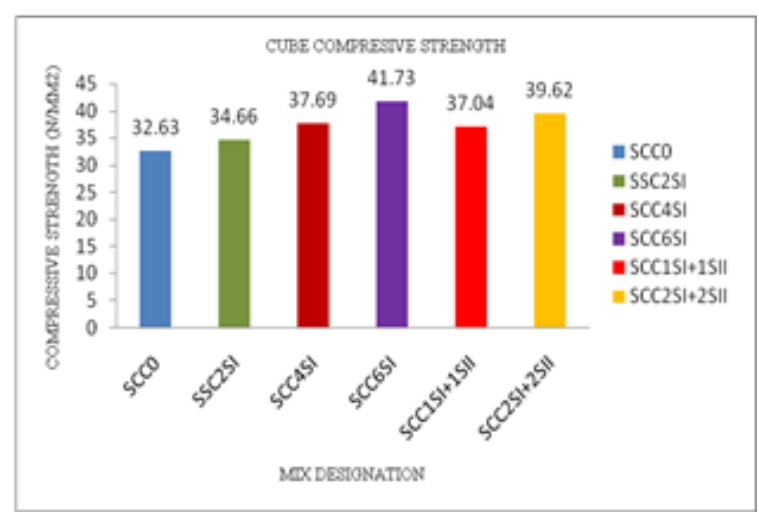

Fig.10.Variation of compressive strength for different mixes

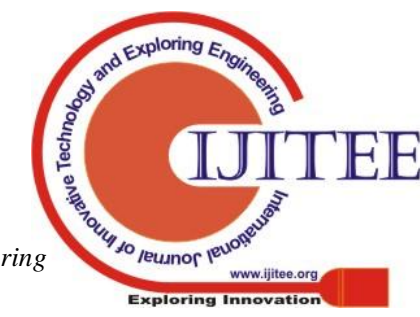




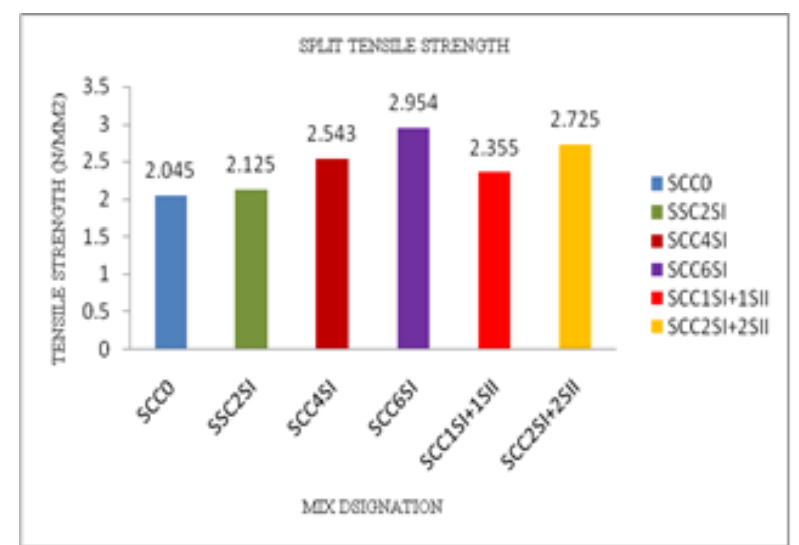

Fig.11.Variation of split tensile strength for different mixes

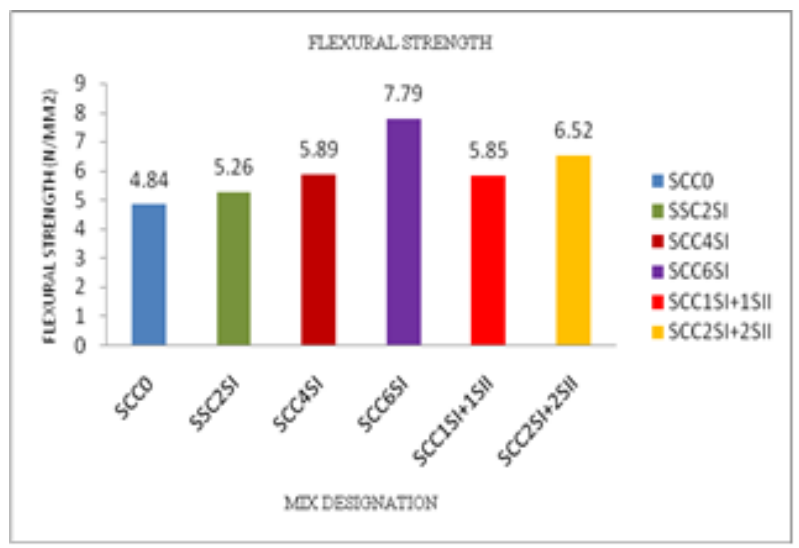

Fig.12.Variation of flexural strength for different mixes

\section{CONCLUSIONS}

Following are the conclusions from the study:

1. As there is an increase in the fiber percentage in the SCC mix the flow properties are adversely affected. Beyond $4 \%$ addition of steel fibers mix is failed to achieve L-box blocking ratio acceptance ratio limits. (TABLE.2.)

2. It shows that by the use of blended fibers in SCC strength properties are increased when compared to the single fiber reinforced SCC.

3. The compressive strength is increased by $11.31 \%$ for the blended fiber reinforced SCC at $1+1 \%$ mix, and increased by $12.25 \%$ at $2+2 \%$ mix, when compared to single fiber reinforced SCC at $2 \%$ and $4 \%$.

4. There is a moderate increase in the split tensile strength of the concrete after the addition of blended fibers.

5. The flexural strength is increased by $11.22 \%$ for the blended fiber reinforced SCC at $1+1 \% \mathrm{mix}$, and increased by $10.69 \%$ at $2+2 \%$ mix, when compared to single fiber reinforced SCC at $2 \%$ and $4 \%$ mix.

\section{ACKNOWLEDGMENT}

The authors are thankful to the Principal of R.V.R\&J.C College of Engineering, and Head of the Department of Civil Engineering for giving permission to avail the available facilities and to publish the results.

\section{REFERENCES}

1. SyalTarun, Goel Sanjay, BhutaniManish.”Workability And Compressive Strength of Steel Polypropylene Hybrid Fiber Reinforced Self-Compacting Concrete." International Journal for Science and Emerging Technologies with Latest Trends" 6(1): 7-13 (2013). BehnamVakhshouri, ShamiNejadi. "Mix design of light-weight self-compacting concrete." Case Studies in Construction Materials 4 (2016) 1-14 atScienceDirect.

2. GandiSathiBabu, P.Rama Mohan Rao."Properties of Self Compacting Concrete usingpoly-Propylene Fibers."SSRG International Journal of Civil Engineering (SSRG-IJCE) volume 3 Issue 3-March 2016.

3. ShaliniMohan , Prof. M. Rajalingam." Steel Fiber Incorporated Self Compacting Concrete." IJISETInternationalJournalofInnovativeScience,Engineering\&Techn ology, Vol.3Issue4, April2016.

4. Mustafa Sahmaran, AlperenYurtseven, I. OzgurYaman." Workability ofhybridfiber reinforced self-compacting concrete." Building and Environment 40 (2005)1672-1677.

5. FarhadAslani ,ShamiNejadi."The self-compacting concrete incorporating steel and polypropylene fibers." composites partB 53(2013) 121-133 at ELSEVIER.

6. NusretBOZKURT, Salih YAZICIOĞLU, Tahir GONEN. "The effect of single and hybrid fibersonfiberReinforcedselfcompactingconcreteproducedwith Highlevelofflyashusage." Constructional Technologies Vol. 5, No 2, December2013.

7. Ahmed Fathi Mohamed Salih ,NasirShafiq ,MuhdFadhilNuruddin, Ali Elheber. "Performance of Fiber Reinforced Self-CompactingConcrete Containing Different PozzolanicMaterial: State of the Art." International Journal Of Civil And Structural Engineering Research (IJCSER) Vol. 1, Issue 1, pp: (22-27), October 2013-March 2014.

8. B H V Pai, Sujith Kumar C.P. "Attempt to present the results of an experimental investigation carried out on high performance steel fiber reinforced self-compacting concrete (SFRSCC)." 34th Conference on our world in concrete \& structures: 16 - 18 August 2009, Singapore.

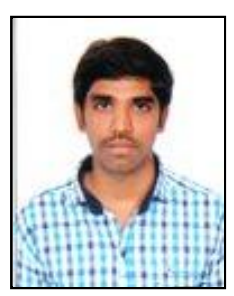

Sk.Noor Ibrahim holds the position of Assistant Professor of Civil Engineering at "VASIREDDY VENKATADRI INSTITUTE OF TECHNOLOGY". He has done his M.tech from "R.V.R\&J.C COLLEGE OF ENGINEERING" in the 2018 academic year in the specialization of structural engineering with distinction. He has completed his B.Tech from "R.V.R\&J.C COLLEGE OF ENGINEERING" in the department of civil engineering with distinction in the academic year 2016. He hails from the state of Andhra Pradesh, Guntur district.

Contact number: +91 8367479113, sk.ibm897@ gmail.com 


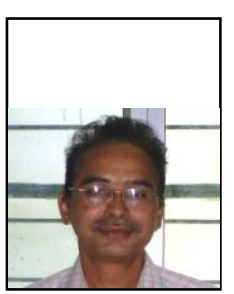

S.V.Sathyanarayanaholds the position of Assistant Professor of Civil Engineering at "R.V.R\&J.C College of Engineering". He has done his M.tech from JNTU-College of Engineering Anantapur in the year2013. in the specialization of structural engineering with distinction. He has completed his B.Tech from University College of Engineering, Osmania University, Hyderabad. He has 20 years of teaching experience and consultancy work experience. He hails from the state of Andhra Pradesh, Guntur district.

Contact number: +91 9440085251, svsatya@ rvrjcce.ac.in

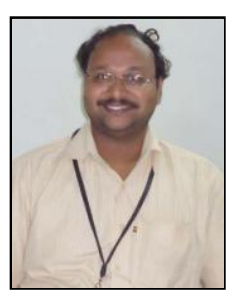

M.L.N Krishna saiholds the position of Assistant Professor of Civil Engineering at "R.V.R\&J.C College of Engineering". He has done his M.E from College of Engineering, Guindy, Anna University, TamilNadu,India. He has completed B.Tech from ANU Affliated College, Andhra Pradesh,India.He has 3 years of industrial experience and 11 years of teaching experience. He hails from the state of Andhra Pradesh, Guntur district.

Contact number: +91 9440644536, mlnks@rvrjcce.ac.in 